\title{
КОМПЛЕКСНИЙ АНАЛІЗ Й ОЦІНЮВАННЯ ІНСТИТУЦІЙНӦ̈ СПРОМОЖНОСТІ ДЕРЖАВНИХ ФІСКАЛЬНИХ ОРГАНІВ У СФЕРІ МІЖНАРОДНИХ ТОРГОВО-ЕКОНОМІЧНИХ ВІДНОСИН
}

Статтю присвячено дослідженню проблеми формування методичного підходу до аналізу й оцінювання інституційної спроможності державних фіскальних органів у сфері міжнародних торговельно-економічних відносин.

В результаті проведеного дослідження розроблено комплексну методику, яка дозволяє оцінити інституиійну спроможність податкових та митних органів. Пропонована комплексна система оцінювання ц̆ аналізу формується виходячи з позицій управлінської дочільності з метою забезпечення оптимізації результатів виконання функції Державної податкової служби у сфері зовнішньоекономічної діяльності з урахуванням специфіки сфери міжнародної торгівлі, сформованого внутрішнього середовища діяльності Державної податкової служби та наявних кадрових, інформаційних та інших ресурсів. При цььому враховані цілі $і$ завдання служби, особливості професійної діяльності ії працівників та інші особливості організації діяльності Державної податкової служби. Вибір напрямів оцінювання інституційної спроможності відповідає основним цілям, завданням, функціям й повноваженням Державної податкової служби у сфері зовнішньоекономічної діяльності $i$ враховує специффку ї̈ діяльності, обумовлену відповідними нормативними правовими актами.

Застосування методики аналізу й оцінювання інституційної спроможності фіскальних органів дасть змогу більш ефективно виконувати покладені на них функиії та управляти їх діяльністю відповідно до встановлених цілей ц̌ завдань шляхом визначення рівня відповідності конкретних параметрів їх діяльності встановленим критеріям.

Пропонована методика відповідає заявленим принщипам та встановленим вимогам щодо достовірності й інформативності результату та дозволяє врахувати всі найбільш значущі параметри діяльності податкових органів. Отримані результати є методологічним та методичним підгрунтям для подальших прикладних розробок та рекомендащій щуодо підвищення інституційної спроможності податкових та митних органів.

Ключові слова: інституційна спроможність, методика оцінювання, фіскальні органи, податкова політика, міжнародні торговельно-економічні відносини.

А.Б. НАУМОВ

Национальный авиационный университет ORCID: 0000-0003-4808-0241

O.B. НАУМОВА

Херсонский национальный технический университет ORCID: 0000-0002-1646-6900

\section{КОМПЛЕКСНЫЙ АНАЛИЗ И ОЦЕНКА ИНСТИТУЦИОНАЛЬНОЙ СПОСОБНОСТИ ГОСУДАРСТВЕННЫХ ФИСКАЛЬНЫЕ ОРГАНЫ В СФЕРЕ МЕЖДУНАРОДНЫХ ТОРГОВО- ЭКОНОМИЧЕСКИХ ОТНОШЕНИЙ}

Статья посвящена исследованию проблемь формирования методического подхода к анализу и оценке институциональной способности государственных фискальных органов в сфере международньх торгово-экономических отночений.

В результате проведенного исследования разработана комплексная методика, которая позволяет оценить институциональную способность налоговых и таможенных органов. Предлагаемая комплексная система оценки и анализа формируется исходя из позиций управленческой целесообразности с целью обеспечения оптимизации результатов выполнения функции Государственной налоговой службы в сфере внешнеэкономической деятельности с учетом специфики сферы международной торговли, сформированной внутренней среды деятельности Государственной налоговой службы и имеющихся кадровых, информаџионных и других ресурсов. При этом учтены цели и задачи службы, особенности профессиональной деятельности ее работников и другие особенности 
организации деятельности Государственной налоговой службы. Выбор направлений оценки институциональной способности соответствует основным целям, задачам, функииям и полномочиям Государственной налоговой службы в сфере внешнеэкономической деятельности и учитывает специфику ее деятельности, обусловленную соответствующими нормативными правовыми актами.

Применение методики анализа и оценки институциональной способности фискальных органов позволит более эффективно выполнять возложенные на них функиии и управлять их деятельностью в соответствии с установленными целями и задачами путем определения уровня соответствия конкретных параметров их деятельности установленным критериям.

Предлагаемая методика соответствует заявленным принципам и установленным требованиям достоверности и информативности результата и позволяет учесть все наиболее значимые параметры деятельности налоговых органов. Полученные результаты являются методологической и методической основой для дальнейших прикладных разработок и рекомендащий по повышению институциональной способности налоговых и таможенных органов.

Ключевые слова: институцииональная способность, методика оценки, фискальные органы, налоговая политика, международные торгово-экономические отношения.

O.B. NAUMOV

National Aviation University

ORCID: 0000-0003-4808-0241

O.V. NAUMOVA

Kherson National Technical University ORCID: 0000-0002-1646-6900

\section{COMPREHENSIVE ANALYSIS AND ASSESSMENT OF INSTITUTIONAL ABILITY OF STATE FISCAL BODIES IN THE INTERNATIONAL TRADE AND ECONOMIC RELATIONS SPHERE}

The article is devoted to the study the problem of formation the methodological approach to analysis and assessment of the institutional ability of state fiscal bodies in the international trade and economic relations sphere.

As a result of the study, has been developed the comprehensive methodology that makes it possible to assess the institutional ability of tax and customs authorities. The proposed comprehensive assessment and analysis system is formed based on the position of managerial feasibility in order to optimize the results of realization the function of the State Tax Service in the foreign economic activity sphere, taking into note the specifics of international trade sphere, the formed internal environment of the State Tax Service and available human, information and other resources.

At the same time, we taken into note the goals and objectives of the service, the features of the professional activities of its employees and other features of the organization of the activities of the State Tax Service. The choice of directions for assessing institutional ability corresponds to the main goals, tasks, functions and powers of the State Tax Service in the foreign economic activity sphere and takes into note the specifics of its activities, due to the relevant regulatory legal acts.

The application of the methodology for analysing and assessing the institutional ability of fiscal bodies will make it possible to more effectively perform the functions assigned to them and manage their activities in accordance with the established goals and objectives by determining the level of compliance the specific parameters of their activities with the established criteria.

The proposed methodology complies with the stated principles and the established requirements for the reliability and information content of the result and allows taking into note all the most significant parameters of the tax authorities' activities. The obtained results are the methodological and methodological basis for further applied developments and recommendations for increasing the institutional capacity of tax and customs authorities.

Key words: institutional capacity, assessment methodology, fiscal authorities, tax policy, international trade and economic relations.

\section{Постановка проблеми}

Актуальність розробки комплексної методики оцінки й аналізу інституційної спроможності фіскальних органів зумовлена тим, що якість державного податкового регулювання у сфері зовнішньоекономічних відносин багато в чому залежить від ефективного і результативного виконання податковими органами, покладених на них функцій.

У зв'язку з цим аналіз й оцінка інституційної спроможності мають враховувати специфічні цілі і завдання податкового органу та специфіку виконуваних завдань й функцій.

Аналіз останніх досліджень і публікацій

Поняття «інституційна спроможність» бере свій початок з інституціональної економічної теорії 
та нової інституціональної теорії $[1,2]$. Економічною наукою визначені базові моделі й структурні складові інституційної економіки, а також основні поняття [3-5].

Інституційна спроможність визначається як процес, результат, інституційна якість [6], властивість управління, організаційна характеристика, фактор управління тощо [7] або, більш конкретно, .як спроможність держструктури ефективно реалізовувати найбільш важливі функції держави та здійснювати контроль за їх виконанням [8].

Не зважаючи на прискіпливу увагу до проблеми інституційної спроможності державних органів з боку науковців й практиків, досі недостатньо розробленими залишаються питання методології та методики її оцінювання, що пов'язано із необхідністю враховувати численні фактори впливу: специфіка державного устрою, стан економіки, зміни у глобальному середовищі тощо. Пропоноване дослідження спрямовано на заповнення цієї прогалини, зокрема на формування конкретних методичних рекомендацій щодо оцінювання інституційної спроможності фіскальних органів у сфері зовнішньоекономічної діяльності (ЗЕД).

\section{Формулювання мети дослідження}

Метою дослідження $є$ формулювання методологічних положень та розроблення методичного підходу до оцінювання інституційної спроможності фіскальних органів у сфері міжнародних торговельно-економічних відносин у контексті інтенсифікації процесів глобалізації.

\section{Викладення основного матеріалу дослідження}

Комплексна оцінка й аналіз інституційної спроможності державних податкових органів у сфері міжнародної торгівлі базується на методологічних принципах організаційної діагностики й передбачає систематичний збір і аналіз інформації про стан податкової системи та ії окремих підсистем з метою виявлення проблем функціонування та визначення шляхів їх подолання.

Діагностика стану інституційної спроможності фіскальних органів є комплексом методів $\mathrm{i}$ прийомів дослідження цієї системи, що дозволяє у визначені терміни із мінімумом витрат ресурсів отримати чітке уявлення про іiі здатність виконувати покладені на фіскальні органи специфічні функції, виявити проблеми та можливі шляхи їх вирішення, ініціювати позитивні зміни у структурі та організації системи й мобілізувати ресурси для їх реалізації.

Комплексна оцінка й аналіз інституційної спроможності фіскальних органів, як дослідницька процедура, здійснюється із дотриманням принципів наукового дослідження, але вона спрямована не на пошук універсальних закономірностей i загальну типізацію проблемних питань, а на виявлення специфічних проблем конкретно фіскальних органів та пошук шляхів їх подолання в умовах розвитку міжнародних торгово-економічних відносин та відповідних зовнішніх й внутрішніх викликів.

Застосування методики аналізу й оцінювання інституційної спроможності фіскальних органів дасть змогу більш ефективно виконувати покладені на них функції та управляти їх діяльністю відповідно до встановлених цілей й завдань шляхом визначення рівня відповідності конкретних параметрів їх діяльності встановленим критеріям.

Окрім того, використання пропонованих методичних підходів, дозволить сформувати умови для ефективного управління структурою, організацією, кадровим складом Державної податкової служби (ДПС), включаючи прийняття обгрунтованих рішень відповідно до трендів розвитку міжнародних торгово-економічних відносин.

Визначення конкретних напрямків оцінювання інституційної спроможності ДПС здійснюється із урахуванням внутрішніх структурних взаємозв'язків, необхідності забезпечення їх прозорості, що дає змогу виявити внесок кожної складової у загальний показник рівня інституційної спроможності ДПС, що дозволяє встановити орієнтири та $\epsilon$ мотивуючим фактором для більш ефективного і результативного виконання функціональних обов'язків податкового органу.

\section{Характеристика методики}

Пропонована методика оцінки інституційної спроможності ДПС у сфері ЗЕД включає в себе опис основних етапів і підходів здійснення такої оцінки.

Цілями методики $є$ такі:

Стратегічна мета - створення нормативних та методичних умов здійснення оцінювання та обгрунтування шляхів підвищення інституційної спроможності ДПС у сфері міжнародних торговельноекономічних відносин, 3 метою забезпечення постійного підвищення результативності діяльності фіскальних органів, більш ефективного виконання ними покладених на них завдань й функцій.

Поточні цілі оцінювання - виявлення відхилень рівня та вектору інституційної спроможності ДПС у сфері ЗЕД та обгрунтування керівних рішень щодо коректування діяльності ДПС з метою забезпечення та підтримки стабільно високого рівня іiі інституційної спроможності, забезпечення виконання покладених на неї завдань й функцій, кількісних і якісних показників ефективності та результативності діяльності ДПС.

Завдання методики: 
- реалізація нових підходів до проведення оцінки інституційної спроможності ДПС в рамках здійснення реформи фіскальних органів, спрямованої на підвищення результативності їх діяльності;

- формування й розвиток єдиної системи оцінювання інституційної спроможності ДПС, яка охоплює всі види, етапи, стадії, оціночні процедури та методи оцінювання, відображує їхній взаємозв'язок й взаємозалежність у процесі реалізації функцій податкових органів;

- отримання ефективного, гнучкого й достовірного результату оцінювання інституційної спроможності ДПС на засадах чіткого нормування всіх етапів, стадій, методів й оціночних процедур;

- забезпечення об’єктивного оцінювання інституційної спроможності, ефективності та результативності діяльності ДПС у сфері ЗЕД.

Методика повинна забезпечувати достовірність результатів оцінювання, можливість їх перевірки й заперечування, об'єктивність і неупередженість експертів, врахування думки зовнішніх експертів і користувачів державних послуг.

В результаті оцінювання можливе забезпечення та стимулювання постійного підвищення інституційної спроможності, ефективності та результативності реалізації функцій та завдань ДПС у сфері ЗЕД, як за окремими напрямками, так і в цілому по службі.

Розробка показників інституційної спроможності ДПС є важливим елементом реформування системи державних фіскальних органів, що передбачає реалізацію функціональної моделі служби орієнтація на досягнення конкретного результату.

Предметом оцінювання $\epsilon$ інституційна спроможність податкових органів, що розкривається через сукупність критеріїв, які характеризують інституційне, організаційне, кадрове, інформаційне забезпечення діяльності фіскальних органів, систему адміністрування та процедури роботи з платниками податків і зборів у сфері міжнародних торговельно-економічних відносин, а також податкові ризики у сфері ЗЕД.

Застосування Методики грунтується на таких принципах:

- принцип законності передбачає обов'язкове дотримання вимог законодавчих та інших нормативно-правових актів при проведенні оцінювання та використанні його результатів;

- принцип системності передбачає, що всі види оцінки (індивідуальна - проведена кожним експертом; оцінка за окремими блоками; сукупна та ін.) розглядаються у взаємозв'язку один 3 одним, як елементи єдиної системи оцінювання інституційної спроможності ДПС.

- принцип забезпечення об'єктивності оцінювання та порівнянності результатів, тобто методологічної єдності використовуваних підходів та оціночних процедур, а також об'єктивності й неупередженості експертів;

- принцип результативності та ефективності діяльності ДПС передбачає, що оцінка інституційної спроможності повинна здійснюватися на основі конкретних показників у оцінюваному періоді;

- принцип економічної доцільності - оціночні процедури мають бути маловитратними 3 точки зору фінансових й часових ресурсів;

- принцип єдності підходів і універсальності процедур - проведення оцінки у різні часові періоди повинне відбуватися за однаковими критеріями й показниками;

Основним методичним підходом, що використовується у пропонованій методиці експертне оцінювання.

Eксnерт - це особа, що володіє необхідними спеціальними знаннями, досвідом, й навичками, яка залучається для проведення експертного оцінювання.

Експертне оцінювання інституиійної спроможності ДПС у сфері ЗЕД - процедура оцінювання інституційної спроможності ДПС у сфері ЗЕД за встановленими критеріями на основі узагальнення думки групи експертів.

Зовнішне експертне оцінювання інституційної спроможності ДПС у сфері ЗЕД - це процедура оцінювання за встановленими критеріями на основі групової думки експертів, до якої обов'язково залучені особи, які є зовнішніми експертами по відношенню до ДПС.

Зовнішня експертна оцінка проводиться у формі анонімного опитування (анкетування).

Анкетне опитування (або анкетування) - є одним з основних видів опитувальних методів. Його суттєвою особливістю $є$ опосередкований характер взаємодії між дослідником (анкетером) й опитуваним (респондентом) через анкету. Респондент - експерт самостійно опрацьовує питання анкети відповідно до наведеної інструкції.

Анкетне опитування є одним 3 найбільш поширених методів, які використовуються при проведенні діагностики організаційних систем.

Перевагами анкетного опитування є такі:

- зручність й порівнянна простота процедури;

- економія ресурсів;

- можливість використання широкого кола експертів (велика вибірка); 
- можливість формалізації результатів.

Проблемним питанням при проведенні анкетування є неможливість контролювати процес заповнення опитувальника (особливо у варіанті заочного анкетування), що може привести до впливу сторонніх осіб на відповіді експерта.

\section{Порядок застосування методики}

У процесі оцінювання інституційної спроможності ДПС у сфері ЗЕД передбачається групове анкетування (залучення групи експертів з числа працівників ДПС, науковців, підприємців, політиків тощо).

За повнотою охоплення генеральної сукупності це вибіркове анкетування (опитування осіб, включених до вибірки), оскільки залучити всіх зацікавлених осіб $є$ технічно й організаційно неможливим.

За типом контактів з респондентом можливе як очне, так і заочне опитування.

Процес опитування складається з таких етапів:

- підготовчий етап - розробка опитувальника, складання плану-графіка дослідження, вирішення організаційних питань;

- власне здійснення опитування;

- первинна обробка отриманих даних;

- розрахунок узагальнюючих показників, аналіз і інтерпретація отриманих даних, розробка рекомендацій і оформлення звіту.

Практичне застосування методики оцінювання інституційної спроможності ДПС у сфері ЗЕД передбачає дотримання таких умов:

- забезпечення ретельного відбору експертів при організації експертної оцінки інституційної спроможності;

- як експертів слід залучати висококваліфікованих фахівців, що мають досвід практичної роботи оціночної діяльності;

- кожен з експертів повинен мати досвід роботи у ДПС або взаємодії з ДПС у рамках своєї професійної діяльності;

- для забезпечення незалежності експертних оцінок при організації роботи експертної групи слід виключити фактори, які могли б впливати на об'єктивність думок експертів;

- питання, включені до опитувальника, повинні бути однозначними, й не допускати множинності тлумачень;

- оцінки експертів повинні забезпечувати можливість їх математичної обробки.

\section{Формування і порядок роботи групи експертів}

Для підвищення об'єктивності результату експертного оцінювання інституційної спроможності ДПС у сфері ЗЕД як експерти повинні залучатися як співробітники ДПС, так і представники інших державних органів, наукових й освітніх установ, бізнес-структур з якими ДПС здійснює регулярні контакти, а також інших організацій, в тому числі, громадських об'єднань;

До незалежних експертів доцільно поставити такі вимоги: вища освіта; додаткова спеціалізація (знання) в галузі оподаткування та/або ЗЕД; проведення наукових досліджень у сфері оподаткування та/або ЗЕД; компетентність та авторитет серед фахівців у професійних колах; досвід державної служби або співпраці з органами державної влади 3 питань оподаткування та/або ЗЕД; високі особистісні характеристики, як зважена, тактовна поведінка, орієнтованість на результат, принциповість, вміння дискутувати; відсутність конфлікту інтересів та особистої зацікавленості в результатах оціночної процедури.

Добір експертів здійснюється уповноваженою на проведення оцінювання особою, за погодженням із замовником експертизи. Перед проведенням оцінювання інституційної спроможності ДПС необхідно ознайомити експертів із інструкцією й забезпечити дотримання ними вимог проведення оцінювання.

Експертна оцінка інституційної спроможності ДПС у сфері ЗЕД проводиться за спеціально розробленим опитувальником, який складається з трьох частин (блоків):

- перша, спрямована на оцінку інституційного забезпечення діяльності фіскальних органів;

- друга містить показники оцінки системи адміністрування податків та зборів у сфері міжнародних торговельно-економічних відносин;

- третя частина спрямована на оцінювання роботи ДПС із платниками податків й зборів у сфері ЗЕД.

Напрямки (блоки) оцінювання інституційної спроможності ДПС показані у табл. 1 
Таблиця 1

Напрямки (блоки) оцінювання інституційної спроможності ДПС у сфері ЗЕД

\begin{tabular}{|c|c|c|}
\hline & Блок & Базові складові блоку \\
\hline \multirow{6}{*}{ 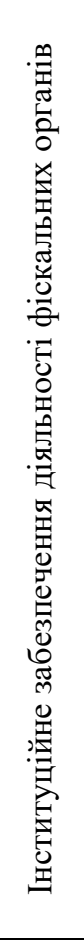 } & $\begin{array}{l}\text { Організаційні засади } \\
\text { діяльності ДПС }\end{array}$ & $\begin{array}{l}\text { Рівень автономії. Структура та функціональна ефективність. } \\
\text { Фінансове забезпечення (бюджет). Контроль та оцінювання } \\
\text { діяльності. Система управління якістю. Опис робочих процесів }\end{array}$ \\
\hline & $\begin{array}{l}\text { Нормативно-правова база } \\
\text { діяльності ДПС }\end{array}$ & $\begin{array}{l}\text { Принципи нормотворчості. Ієрархія податкового законодавства. } \\
\text { Права та обов'язки платників податків. Відповідальність платників } \\
\text { податків за невиконання податкового обов'язку. Роль ДПС у } \\
\text { нормотворчому процесі }\end{array}$ \\
\hline & $\begin{array}{l}\text { Кадрові засади діяльності } \\
\text { ДПС }\end{array}$ & $\begin{array}{l}\text { HR-стратегія. Чисельність та плинність персоналу. Кількісний та } \\
\text { якісний склад персоналу. Мотивація (матеріальна та нематеріальна). } \\
\text { Стандарти етики та доброчесності, імунітет працівника. Добір та } \\
\text { оцінювання персоналу. Розвиток персоналу }\end{array}$ \\
\hline & $\begin{array}{c}\text { Умови реалізації } \\
\text { функціональних обов'язків } \\
\text { працівників ДПС (робоча } \\
\text { екосистема) } \\
\end{array}$ & $\begin{array}{l}\text { Організація внутрішнього розпорядку та безпека. Психологічна } \\
\text { підтримка / психологічна адаптація. Організація індивідуального } \\
\text { робочого простору. Безпечні умови праці }\end{array}$ \\
\hline & $\begin{array}{c}\text { IT та інформаційне } \\
\text { середовище функціонування } \\
\text { податкових органів (IT- } \\
\text { архітектура та бази даних) }\end{array}$ & $\begin{array}{l}\text { IT-стратегія. Інтеграція IT з базами даних інших відомств та третіх } \\
\text { осіб (банків, страхових компаній та ін.). Рівень фінансування IT- } \\
\text { проєктів. Безпека даних та заходи протидії кіберзлочинності. IT- } \\
\text { автономність. Рівень автоматизації робочих процесів }\end{array}$ \\
\hline & $\begin{array}{l}\text { Міжнародне співробітництво, } \\
\text { імплементація міжнародних } \\
\text { норм і правил, стандартів, } \\
\text { угод тощо } \\
\end{array}$ & $\begin{array}{l}\text { Міжнародні податкові договори. Міжнародні зобов'язання. } \\
\text { Міжнародні стандарти в роботі. Обмін податковою інформацією } \\
\text { (автоматичний або за запитами) }\end{array}$ \\
\hline \multirow{4}{*}{ 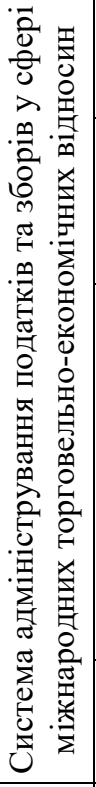 } & $\begin{array}{l}\text { Система обліку платників та } \\
\text { об’єктів оподаткування }\end{array}$ & $\begin{array}{l}\text { Ідентифікація та реєстрація платників податків (паспорт платника, } \\
\text { можливість електронної реєстрації платником самостійно тощо). } \\
\text { Системи обліку (реєстри, оновлення інформації) }\end{array}$ \\
\hline & $\begin{array}{l}\text { Система адміністрування, } \\
\text { нарахування, обліку та } \\
\text { збирання податків й зборів }\end{array}$ & $\begin{array}{l}\text { Систематичне вдосконалення системи адміністрування. Податкова } \\
\text { звітність. Сплата податків та моніторинг. Робота з податковим } \\
\text { боргом. Процедури повернення коштів (відшкодування податкової } \\
\text { знижки, переплат, податкових кредитів) }\end{array}$ \\
\hline & $\begin{array}{c}\text { Система управління } \\
\text { податковими ризиками, } \\
\text { посилення контрольної } \\
\text { функції }\end{array}$ & $\begin{array}{l}\text { Перелік інституційних і податкових ризиків та план їх мінімізації. } \\
\text { Сегментація платників за ступенем ризикованості. Удосконалення } \\
\text { процедур податкового аудиту. Автоматизація податкового аудиту. } \\
\text { Моніторинг та оцінка ефективності податкових перевірок. } \\
\text { Моніторинг обсягів та ступеня ухилення від оподаткування, оцінка } \\
\text { tax gар. Моніторинг обігу товарів. Слідчі функції та повноваження } \\
\text { ПВ. Інтелектуальні системи аналізу податкових надходжень. } \\
\text { Податковий контроль за операціями з крипто валютами. Заходи з } \\
\text { реалізації трансфертного ціноутворення та ініціатив BEPS. }\end{array}$ \\
\hline & $\begin{array}{c}\text { Забезпечення } \\
\text { зовнішньоекономічної } \\
\text { безпеки держави } \\
\end{array}$ & $\begin{array}{l}\text { Аналіз й оцінка факторів зовнішньоекономічної безпеки. Стратегія } \\
\text { забезпечення митної безпеки }\end{array}$ \\
\hline \multirow{4}{*}{ 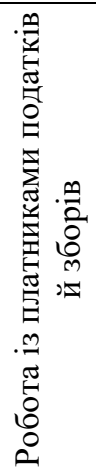 } & Комунікаційні системи & $\begin{array}{l}\text { Наявні канали комунікації. Комунікаційна та іміджева стратегія. } \\
\text { Взаємодія з бізнесом та громадськістю. Зворотний зв'язок }\end{array}$ \\
\hline & $\begin{array}{c}\text { Система надання податкових } \\
\text { послуг }\end{array}$ & $\begin{array}{l}\text { Сервісні центри, кол-центри. Онлайн (електронні) сервіси. } \\
\text { Електронні документи. Автоматичне формування декларацій }\end{array}$ \\
\hline & $\begin{array}{l}\text { Система добровільного } \\
\text { комплаєнсу }\end{array}$ & $\begin{array}{l}\text { Комплаєнс стратегія. Планування роботи у сфері добровільного } \\
\text { комплаєнсу. Заходи стимулювання добровільного комплаєнсу. } \\
\text { Зниження транзакційних витрат на виконання податкового } \\
\text { обов'язку }\end{array}$ \\
\hline & $\begin{array}{l}\text { Система вирішення } \\
\text { податкових спорів }\end{array}$ & $\begin{array}{l}\text { Механізми та рівні розгляду скарг платників податків. Практика } \\
\text { альтернативних методів вирішення спорів. Аналіз ефективності } \\
\text { адміністративного оскарження }\end{array}$ \\
\hline
\end{tabular}


Оцінка може проводитися як за усіма напрямками оцінювання, зазначеними у таблиці, так і за окремими з них. Для забезпечення об'єктивності оцінки, що враховує багатоаспектність завдань, що постають перед податковою службою, доцільно використовувати всі напрями оцінювання.

Можлива двохетапна організація використання методики для оцінювання інституційної спроможності ДПС.

На першому етапі оцінка проводиться лише із залученням експертів - працівників ДПС, що дозволяє виділити внутрішній погляд, тобто самооцінку сильних й слабких сторін ДПС, намітити напрямки подальшого розвитку.

На другому етапі, для підвищення інформативності процедури оцінювання інституційної спроможності, до оцінки залучаються зовнішні експерти.

Використання двохетапної процедури оцінювання інституційної спроможності ДПС дає змогу здійснити порівняльний аналіз результатів роботи двох груп експертів - «внутрішніх» й «зовнішніх» та отримати більш повну інформацію про стан інституційної спроможності ДПС, ніж при аналізі середніх оцінок по всій групі експертів.

За кожною складовою блоків визначено спеціальні складові - оціночні параметри. Кожен параметр подано у вигляді питання, яке передбачає такі варіанти відповіді: «так» чи «ні», на окремі питання також можлива відповідь «частково». Кожен варіант відповіді має власну бальну оцінку, наприклад: «так» - 1 бал, «частково» - 0,5 бали, «ні» - 0 балів.

Визначення підсумкової оцінки здійснюється шляхом підсумовування отриманих бальних оцінок за показниками (спеціальними складовими блоків) і визначення ступеня досягнення максимально можливого результату (максимальної оцінки). Мінімально можлива оцінка - 0 балів (негативні відповіді на всі питання), максимальна оцінка - загальна сума балів за відповіді «так» на всі питання.

Визначення підсумкової оцінки інституційної спроможності ДПС в умовах розвитку міжнародних торгово-економічних відносин здійснюється у такій послідовності:

- відповіді експертами на поставлені питання;

- підсумовування бальних оцінок інституційної спроможності для кожного експерта; оцінкою;

- розрахунок середньої оцінки за групою експертів та співвіднесення ії з максимально можливою

- переведення розрахованої суми бальних оцінок в процентний показник, що характеризує відхилення фактичного (досягнутого) значення суми підсумкових оцінок від максимально можливого значення даного показника.

Підсумкову оцінку інституційної спроможності ДПС у сфері міжнародної торгівлі рекомендується визначати на основі внутрішньої та зовнішньої інформації, доступної експертам із урахуванням думки громадськості та суб'єктів ЗЕД, із наступним переведенням значення у процентний показник, що характеризує відхилення фактичного (досягнутого) значення показника від його максимально можливого значення, що представляє собою «найкращу» оцінку, яка могла б бути отримана в ході експертного опитування.

Розрахунок підсумкової оцінки інституційної спроможності ДПС рекомендується здійснювати шляхом підсумовування оцінок по кожному 3 блоків оцінювання, виражених у відсотках від максимально можливого результату, що дає змогу проводити детальний аналіз інституційної спроможності та визначати ключові напрямки її покращення.

\section{Інтерпретація результатів}

Аналіз результатів опитування експертів передбачає вирішення таких основних завдань: експертів;

- отримання узагальненої оцінки інституційної спроможності ДПС у сфері ЗЕД на основі оцінок експертів.

- якісна оцінка результатів дослідження на основі визначення рівня узгодженості думок

Для побудови узагальненої оцінки інституційної спроможності ДПС у сфері ЗЕД на основі оцінок експертів доцільно використовувати шкалу інтервалів, що дозволяє застосовувати всі звичайні статистичні заходи (методи аналізу і обробки даних).

Пропонована шкала інтервалів для оцінювання інституційної спроможності ДПС у сфері ЗЕД представлена у табл. 2 .

Визначення рівня узгодженості думок експертів проводиться за допомогою обчислення коефіцієнта варіації значення показника IC. Відсутність узгодженості експертних оцінок (коефіцієнт варіації більший за 33\%) може бути наслідком складності оцінювання певних параметрів, упередженості думок або недостатнього рівня кваліфікації самого експерта. Тому при аналізі результатів експертного оцінювання не рекомендується приймати до уваги оцінки, які суттєво відрізняються від середнього значення по експертній групі. 
Таблиця 2

Шкала інтервалів для оцінювання інституційної спроможності (ІС) ДПС у сфері ЗЕД

\begin{tabular}{|c|c|c|}
\hline $\begin{array}{c}\text { Значення } \\
\text { IC }\end{array}$ & Інтервал & Опис \\
\hline $90-100 \%$ & Високий & $\begin{array}{l}\text { ДПС повною мірою виконує покладені на неї функції у сфері } \\
\text { регулювання ЗЕД за всіма напрямками. Інституційне, адміністративне, } \\
\text { організаційне, інформаційне забезпечення знаходиться на високому рівні. } \\
\text { Відбувається попередження виникнення ризикових ситуацій у сфері ЗЕД. } \\
\text { Втручання у систему не потрібне. }\end{array}$ \\
\hline $80-89$ & Нормальний & $\begin{array}{l}\text { ДПС належним чином виконує покладені на неї функції у сфері } \\
\text { регулювання ЗЕД за всіма напрямками. Спостерігаються незначні } \\
\text { відхилення у рівнях інституційного, адміністративного, організаційного, } \\
\text { інформаційного забезпечення. Втім, їх рівень оцінюється як нормальний. } \\
\text { Ризики у сфері ЗЕД є оптимізованими. Необхідне коректування дій дПС } \\
\text { за окремими напрямками. }\end{array}$ \\
\hline $65-79$ & Середній & $\begin{array}{l}\text { ДПС виконує покладені на неї функції у сфері регулювання ЗЕД за } \\
\text { більшістю напрямків, ведеться робота по покращенню виконання } \\
\text { функцій. Спостерігаються суттєві але некритичні відхилення у рівнях } \\
\text { інституційного, адміністративного, організаційного, інформаційного } \\
\text { забезпечення. Їх рівень оцінюється як середній. Ризики у сфері ЗЕД } \\
\text { контрольованими. Необхідне удосконалення діяльності ДПС за } \\
\text { основними напрямками. }\end{array}$ \\
\hline $35-64$ & Критичний & $\begin{array}{l}\text { ДПС виконує покладені на неї функції у сфері регулювання ЗЕД не за } \\
\text { всіма напрямками, необхідні термінові заходи щодо покращення } \\
\text { виконання функцій. Спостерігаються критичні відхилення у рівнях } \\
\text { інституційного, адміністративного, організаційного, інформаційного } \\
\text { забезпечення. Ризики у сфері ЗЕД аналізуються але вони є некерованими. } \\
\text { Необхідна суттєва зміна структури та методів роботи ДПС. }\end{array}$ \\
\hline $0-34$ & Незадовільний & $\begin{array}{l}\text { ДПС не виконує покладені на неї функції у сфері регулювання ЗЕД за } \\
\text { ключовими напрямками, необхідні радикальні дії щодо покращення } \\
\text { ситуації. Спостерігаються кризові відхилення у рівнях інституційного, } \\
\text { адміністративного, організаційного, інформаційного забезпечення. Ризики } \\
\text { у сфері ЗЕД є неконтрольованими. Необхідна докорінна змінена системи } \\
\text { ДПС. }\end{array}$ \\
\hline
\end{tabular}

Систематичне проведення оцінювання інституційної спроможності ДПС у сфері ЗЕД (бажано відносно стабільним складом групи експертів) дає можливість нагромадження масиву статистичних даних як власне про рівень інституційної спроможності, так і про рівень узгодженості думок експертів, тобто про достовірність роботи експертної групи, що дозволяє отримати стійке числове значення оцінки достовірності. Отриману оцінку достовірності можна використовувати як апріорні дані про рівень достовірності роботи експертної групи для проведення наступних опитувань та покращення складу експертної групи.

Отже, отримані у процесі експертного оцінювання дані про рівень інституційної спроможності ДПС у сфері міжнародних торговельно-економічних відносин можуть слугувати орієнтиром при визначенні напрямків удосконалення діяльності податкових органів, а детальний аналіз отриманих оцінок у розрізі блоків та окремих складових дає змогу конкретизувати заходи щодо підвищення спроможності ДПС виконувати покладені на неї функції у сфері ЗЕД.

\section{Висновки}

Побудова комплексної системи оцінювання дає змогу управляти діяльністю ДПС у сфері ЗЕД шляхом діагностики стану та можливостей виконання службою функцій податкового регулювання, грунтуючись на встановлених цілях, завданнях й повноваженнях ДПС. Показники інституційної спроможності ДПС визначаються виходячи з комплексу ії цілей й завдань. За результатами оцінювання можуть бути прийняті необхідні стратегічні й тактичні управлінські, організаційні, кадрові рішення, як в цілому по ДПС, так по іiі структурних підрозділах та окремих напрямках діяльності.

Пропонована комплексна система оцінювання й аналізу формується виходячи 3 позицій управлінської доцільності з метою забезпечення оптимізації результатів виконання функції ДПС у сфері ЗЕД з урахуванням специфіки сфери міжнародної торгівлі, сформованого внутрішнього середовища діяльності ДПС та наявних кадрових, інформаційних та інших ресурсів. При цьому враховані цілі і завдання служби, особливості професійної діяльності їі працівників та інші особливості організації діяльності ДПС. Вибір напрямів оцінювання інституційної спроможності відповідає основним цілям, 
завданням, функціям й повноваженням ДПС у сфері ЗЕД і враховує специфіку іiі діяльності, обумовлену відповідними нормативними правовими актами.

Пропонована методика відповідає заявленим принципам та встановленим вимогам щодо достовірності й інформативності результату та дозволяє врахувати всі найбільш значущі параметри діяльності податкових органів.

\section{Список використаної літератури}

1. Encyclopædia Britannica - URL: https://www.britannica.com/topic/institutional-economics

2. Shinji Teraji, Cognitive basis of institutions, 2018 - URL: https://www.worldcat.org/title/cognitivebasis-of-institutions-a-synthesis-of-behavioral-and-institutional-economics/oclc/1023627978

3. Підопригора О. А. Інституційна система. Архів оригіналу за 24 жовтень 2014. - URL: https://web.archive.org/web/20141024181945/http://www.zakony.com.ua/lawbase.html?catid=39300

4. Міненко М. Інституційна спроможність фахових об’єднань в Україні /М. Міненко // Маркетинг в Україні - 2009. - №3. - С. 42-49

5. Клімчик В.В. Інституційне забезпечення фіскального регулювання зовнішньоторговельної діяльності в Україні / В.В. Климчик// Інноваційна економіка. - 2014. - №4. - С. 79-85.

6. Glossary For New Institutional Economics/ Compiled by Alexandra Benham - In English - URL: https://www.coase.org/nieglossary.htm\#REFGovernancestructure

7. Петренко К. Особливості інституційної спроможності громадських об'єднань в Україні /К. Петренко // Наукові записки ІПіЕНД ім. І.Ф. Кураса НАН України. - 2015. - випуск 4 (78). - С.376-388.

8. Колісніченко Н. Інституційна та інституціональна спроможність місцевого самоврядування: сутність понять та особливості визначення / Колісніченко Н., Войновський М. //Теоретичні та прикладні питання державотворення. - 2015. - №. 16. - С. 296-309.

\section{References}

1. Encyclopædia Britannica. Available at: https://www.britannica.com/topic/institutional-economics (accessed 22 September 2020)

2. Shinji Teraji, Cognitive basis of institutions, London 2018 [e-book]. Available at: https://www.worldcat.org/title/cognitive-basis-of-institutions-a-synthesis-of-behavioral-and-institutionaleconomics/oclc/1023627978 (accessed 22 September 2020).

3. Pidopry`gora O. A. Insty`tucijna sy`stema. Arxiv ory`ginalu za 24 zhovten.`2014. Available at: https://web.archive.org/web/20141024181945/http://www.zakony.com.ua/lawbase.html?catid=39300 (accessed 22 September 2020)

4. Minenko M. Insty ‘tucijna spromozhnist` faxovy`x ob'yednan` v Ukrayini. Markety`ng v Ukrayini, 2009, no3. pp. 42-49

5. Klimchy`k V.V. Insty`tucijne zabezpechennya fiskal`nogo regulyuvannya zovnishn`otorgovel’noyi diyal nosti v Ukrayini. Innovacijna ekonomika, 2014, no 4, pp. 79-85.

6. Glossary For New Institutional Economics. Compiled by Alexandra Benham - In English. Available at: https://www.coase.org/nieglossary.htm\#REFGovernancestructure (accessed 22 September 2020)

7. Petrenko K. Osobly`vosti insty`tucijnoyi spromozhnosti gromads`ky`x ob'yednan`v Ukrayini. Naukovi zapy`sky`IPiEND im. I.F. Kurasa NAN Ukrayiny, 2015, vol 4 (78), pp.376-388.

8. Kolisnichenko N. Insty`tucijna ta insty`tucional’na spromozhnist' miscevogo samovryaduvannya: sutnist` ponyat` ta osobly`vosti vy`znachennya. Teorety`chni ta pry`kladni py`tannya derzhavotvorennya, 2015 , no 16 , pp. 296-309. 